\title{
ゴム加工へのシミュレーションの応用と評価技術 \\ The Simulation and The Characterization for Evaluating Processability of Rubber
}

\author{
佐 藤 有 二
}

(Received on January 6, 2016)

\section{1. は じ め に}

ゴム加工工程では，ゴムは未加硫の状態で大変形を受け 加工される。 この時, ゴム製品の代表格である防振ゴムや ホースといった工業用品や夕イヤ用ゴムには, 過酷な使用 条件に耐え得るだけの機械的強度を与えるために, カーボ ンブラック (CB) やシリカを代表とする補強性充填剂（フ イラー）が充塡されている. しかし，フィラーを充填する 事によりゴム材料は複合材料となり複雑な振る舞いを示す ようになる．特に加工工程で与えられるような大変形条件 下では顕著な非線形性を示す。この非線形性は, ゴムの内 部構造変化によるものであり, その解明が重要である。し たがって, 加工工程におけるゴムの挙動を理解するために は, 未加硫ゴム（他補強層との複合材として取り扱う場合 も含め) の大変形挙動と大変形による未加硫ゴムの内部構 造変化を明らかにする事が重要となる，そこで，本稿では 未加硫ゴムの大変形挙動と内部構造変化について, シミュ レーションと特性評価に基づく検討事例について紹介す る.

\section{2. ゴム加エへのシミュレーションの応用}

コンピューターの処理速度の目覚しい進化を背景に, 現 在では様々な製品・場面において構造解析や流体挙動解析 に対しシミュレーションが適用されており, 新商品のカ夕 ログには必ずと言って良いほどカラフルなシミュレーショ ン結果が記載されると共に商品の優位性が訴えられてい る. シミュレーションによる解析は，このような製品最終 形だけではなく，ゴムの加工工程にも適用が可能である. 例えば, タイヤの成形工程などそれほど大きくない変形領 域おいては, 未加硫ゴムであっても構造体として, 外力に 対する変形挙動をシミュレートする事が可能である。この 時, 夕イヤのような補強層との複合構造になっていても,

*横浜ゴム(株) タイヤ生産技術本部・研究室長

（干 254-8601 神奈川県平塚市追分2-1）
各々の材料を計算モデル中で定義することで複合材として の振る舞いを解析することが可能である(図 1 ).

一方, もう少し大きな変形領域になると構造体としての 取り扱いでは計算上無理が生じてくる，最も顕著であるの は, 有限要素モデル特有のメッシュが変形に伴いつぶれて しまい, それ以上の変形に対して収束解を得られないとい う状況である.この場合には, 変形途中でメッシュを切り なおすリメッシュ法や, メッシュそのもので材料要素を定 義しないフリーメッシュ法などを適用する事で比較的大き な変形 (流動に近い) 挙動をシミュレートする事が可能で ある（図2）。フリーメッシュ法の1つである粒子法をゴム の圧縮成形に適用し，仕込みゴムに見立てた材料を金型で

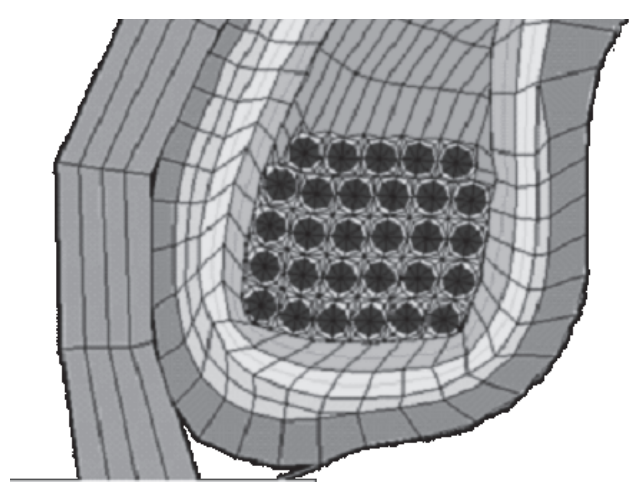

図 1 構造体としての FEM解析事例

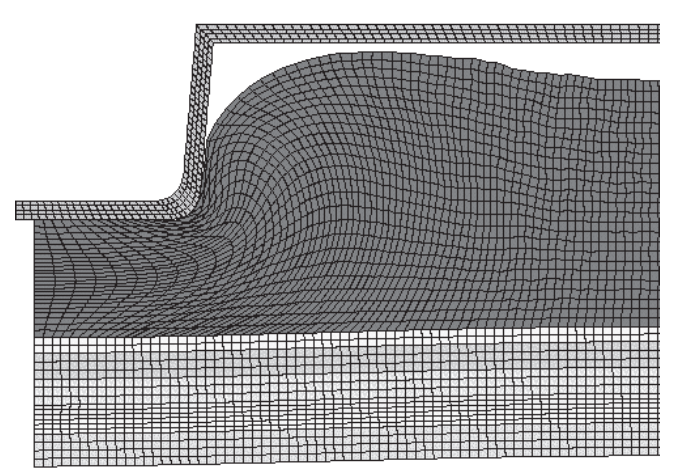

図2 流動を加味したFEM解析事例 
押しつぶし, ゴムの充填状況を確認した結果, 狭い流路へ の流動も再現されることが報告されている ${ }^{1)}$.

更に流動を前提とした射出成形などを想定すると，成形 流動シミュレーションなどを適用することが有効である. 射出成形時の材料流動挙動のシミュレーションは, 樹脂成 形などでは盛んに行われているが, 最近ではゴムの射出成 形シミュレーションの実施例も増えてきている.この時, 材料の流動特性として伸張粘度の影響を加味することで解 析精度の向上が期待されることも報告されている ${ }^{1)}$. また, ゴムが十分に可塑化された状態での振る舞いを再現する場 合には, 流体解析の適用も有用であり, ゴムの混練プロセ ス, 押出プロセスなどでの挙動を再現することができてい る.

以上のように, 加工中の未加硫ゴム（補強層を含めた複 合材としても）の大変形挙動を明らかにするために有限要 素法などのシミュレーションを適用する事は非常に有効で あり, 比較的小さな変形域での挙動に対しては, 未加硫ゴ ムを構造体として取り扱う事で, その変形挙動を見積もる 事が可能である. また, 流動を伴うような大変形領域での 挙動については, リメッシュ法や, メッシュそのもので材 料要素を定義しないフリーメッシュ法などを適用する， あ るいはゴムそのものを流体として定義して成形流動シミュ レーションや流体解析を適用する事で, その挙動を見積も る事が可能である.

ただし，前述のように加工工程におけるゴムの挙動を理 解するためには, このような未加硫ゴムの大変形挙動を明 らかにすると同時に, 大変形による未加硫ゴムの内部構造 変化を明らかにする事が重要である. 最近の動向として は, 分子動力学などを適用しゴム分子鎖と充填されたフィ ラーの運動をシミュレートすると共に, マルチスケール・ シミュレーションなどにより幅広いスケール間での挙動を 見積もる取組みが行われているが, 加工中のゴム中でのゴ ム分子鎖やフィラーの振る舞いそのものを実用レベルで再 現するには至っていないのが実情であり, ゴムの内部構造 を評価する別の手法も必要である.

\section{3. ゴム内部構造評価技術}

ゴム材料は，ゴム分子鎖（ポリマー）とフィラーで構成 されている。 それらの間の相互作用は，ポリマーポリマ 一間, ポリマーノフィラー間, フィラーノフィラー間の相 互作用に大別される。一つ目の相互作用は，分子鎖間の絡 み合い効果によるものである ${ }^{2-6)}$.二盲は主にフィラー ゲル ${ }^{7,8)}$ として現れる. フィラー網目は三つ目の相互作用 により形成される。フフラー網目はごく近傍にあるフィラ 一間で形成されるもの (contact filler network $(\mathrm{CFN}))^{5,8)}$ と, フィラーゲル相に拘束されたゴム分子鎖を介して形成 されるもの (bridged filler network $(\mathrm{BFN}))^{5,7,8)}$ からな
ると考えられる。フフラーゲルは，CB表面とジエンポリ マーの $\pi$ 電子間相互作用のような強い化学的相互作用に基 づくものであると考えられ7,8), 大きなひずみ下でも容易 に消滅することはないであろう.

このような相互作用を持つフィラー充填未加硫ゴムの粘 弾性特性は, 顕著な非線形性（歪振幅依存性）を示す。 (図4)この未加硫ゴムの非線形粘弾性は, 大ひずみによ って誘起される分子鎖配置の異方性, 絡み合い解放, なら びにフィラー網目崩壊に由来すると考えられる. しかし, 未加硫ゴムでは, 分子鎖の異方性は応力緩和の進行ととも に速やかに解消されるはずであるので, 変形から少し時間 が経過した状態で議論すべき対象としては, 絡み合い網目 変化とフィラー網目変化に着目すればよいことになる。し かし, これらの変化はもちろん同時に進行するので, 一つ の粘弾性関数のみの測定では不十分である.これらを分離 して議論するためには，別の指標が必要である.

\section{1 体積抵抗率によるフィラー網目の評価}

ポリマーは絶縁材料である。一方, CB は顕著な導電性 を示し，このCBを十分に配合することで，ゴムに導電性 が発現することはよく知られている ${ }^{10,11)}$ 。これは, CBの 直接的な相互作用による網目 $(\mathrm{CFN})$ の形成を意味する. したがって, もし大変形により CFN が崩壊すれば, ゴム 材料の電気抵抗は増加するはずである。 そこで, 粘弾性関 数と体積抵抗の同時測定が有効である.

ゴム材料評価は, 測定のしやすさから高伸長時の応力 -

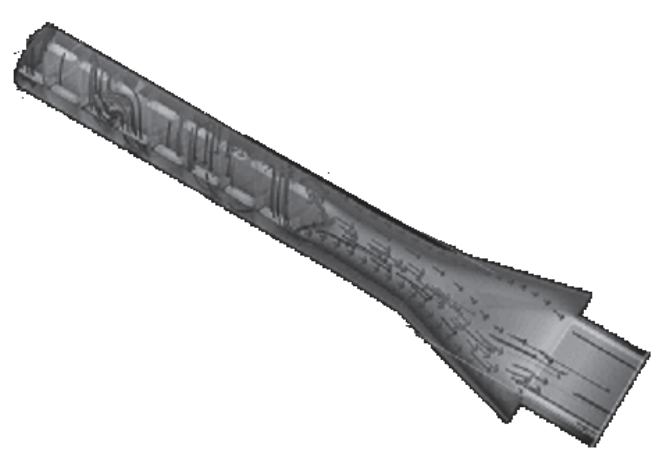

図3 ゴム加工への流体解析適用事例

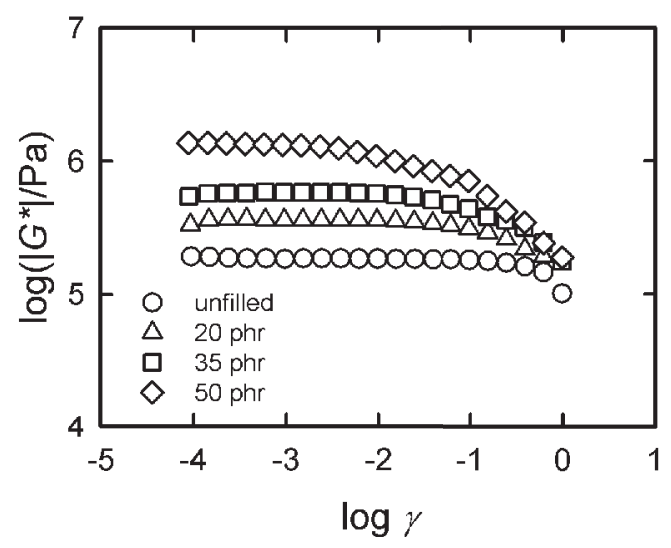

図4 CB 充塡未架橋 SBRに扔ける動的弾性率絶対值の歪振幅依存性 
ひずみ曲線により行われることが多い。しかし，高伸張時 の応力は化学網目が支えている. したがって, この情報か らフィラー網目の評価をする事は難しい. フィラー網目の 評価には, フィラー網目の崩壊が変形時の応力に寄与する 変形様式での評価が必要であり, せん断変形を選択する事 が望ましい.

また,ゴムの粘弾性関数の評価には動的弾性率が用いら れることが多い. 歪振幅の小さい線形粘弾性においては, 応力とひずみのピーク值に加え位相差 $\delta$ 実験的に求める 事が出来, 貯蔵弾性率, 損失弾性率を定義可能で, そこか ら得られる情報は非常に有用である。しかし，歪振幅を大 きくすると応答に非線型性が現れ，応力波は周期波ではあ るが単純な正弦波ではなくなり，平行移動しても歪波に重 ねる事は出来なくなる，つまり，応力波と歪波の間の位相 差 $\delta$ を一意的に決定する事は出来ず, 貯蔵弾性率, 損失弾 性率を求める事は出来ない ${ }^{12)}$. また, 動的弾性率は周期的 な刺激の元で計測されるため, 刺激に対する履歴も不明確 になる。したがって，大変形中のゴムの内部構造変化を正 確に検出するためには非線形域でも定義可能で, 変形履歴 を定量可能な粘弾性関数が必要となる.

上記課題を回避可能な粘弾性関数の 1 つが緩和弾性率時 間依存曲線の高さの変化による非線形評価である。図 5 に さまざまな歪における緩和弾性率時間依存曲線を示すが, 緩和弾性率時間依存曲線は, 歪振幅の変化により並行に高 さ変化する。また，図6に $\mathrm{CB}$ 配合量の異なる試料におけ る変形直後 $(t=0.1 \mathrm{~s})$ の緩和弾性率の歪振幅依存性を示 すが, 変形直後の緩和弾性率はCB配合量が増えるほど顕 著な非線形性（歪振幅依存性）を示し，緩和弾性率の高さ の変化により，非線形性を議論可能である事が分かる。ま た，緩和弾性率はステップ歪による応答をとらえるため, 歪履歴も明確であると同時に，せん断モードでの変形を付 与する事で, フィラー網目の応力への関与を確保出来, 全 ての課題を満足できる.

$\mathrm{CB}$ 未充填, 及び充填量を変更した未加硫 SBR で緩和弾 性率と体積抵抗率の同時測定を行った結果, $\mathrm{CB}$ 充填試料

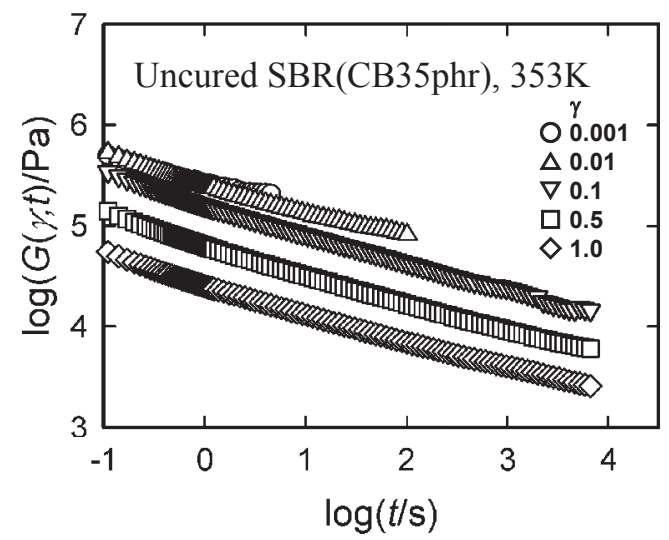

図5様々な歪における緩和弾性率時間依存性
における緩和弾性率の歪振幅依存性と体積抵抗率増加の歪 振幅依存性が確認された（図7）この結果より，フィラ 一未充填試料における緩和弾性率の非線形挙動は, ゴム分 子鎖の絡み合い網目構造の変化によるもの, フィラー充填 試料のおける非線形挙動は, 絡み合い網目構造変化に加え フィラー網目構造変化によるのもと判断される. また, フ イラー充填量が $35 \mathrm{phr}$ とパーコレーション閾值よりも高 い試料においては CFNの崩壊による影響が大きく，パー コレーション閾值よりも低い $20 \mathrm{phr}$ の試料ではBFNの崩 壊による影響が大きい事が示唆される。

\section{2 粘弾性関数によるフィラー網目評価}

前節では，フィラーとしてCBを充填した場合において， $\mathrm{CB}$ の電気導電性を利用してフィラー網目を評価する手法 について述べた。しかし，最近のタイヤトレッド用ゴムを 代表にフィラーとしてシリカを充填することが増えてい る. シリカ充填ゴムにおいても, シリカに吸着する水分の 寄与によりフィラー網目形成により僅かな電気伝導パスが 形成し, 高抵抗中ながらもフィラー網目崩壊にともなう電 気伝導度の変化が生じるのではあるが, 変形と同時にこの

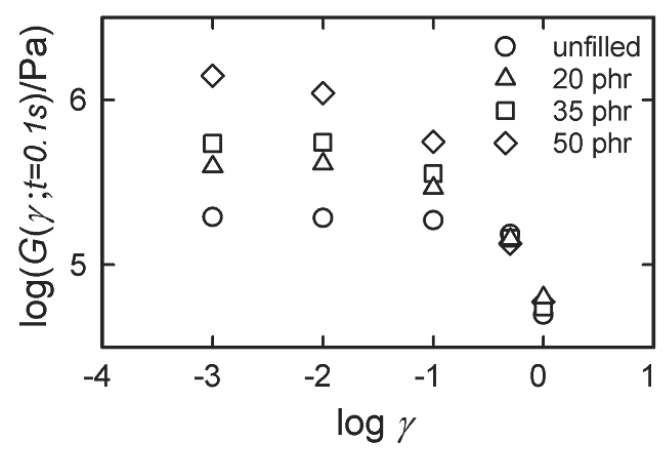

図 6 変形直後 $(t=0.1 \mathrm{~s})$ の緩和弾性率歪振幅依存性
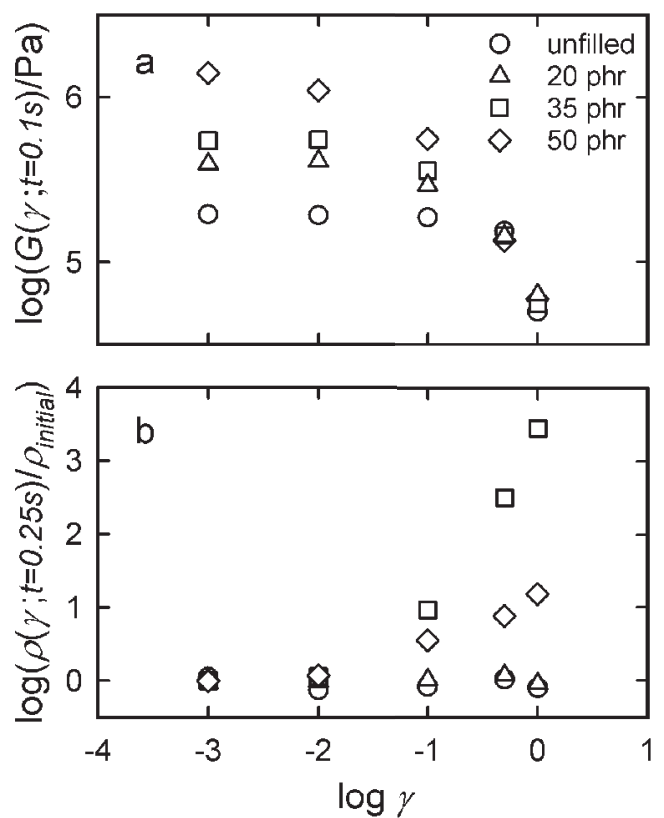

図 7 初期緩和弾性率（a）と体積抵抗率の初期変化率（b）の歪振幅 依存性 
僅かな電気抵抗の変化を精度良く観測する事は困難であ る.したがって，シリカによるフィラー網目の評価のため には電気抵抗測定に代わる新たなプローブが必要である.

粘弾性関数によるフィラー網目の評価に関しては, 架橋 試料の大圧縮後の変形回復過程に微小振動を重畳すること で測定される微分動的弾性率により，CB充填試料における フィラー網目の評価が可能なことが報告されている ${ }^{2,4,6)}$. この微分動的弾性率は, 大変形に重畳する微小な動的歪に 対する応答より定義するので, 位相差 $\delta$ を実験的に求める 事が可能である。また，図8に示すように未加硫 $\mathrm{CB}$ 充填 試料において, 前節同様の緩和弾性率と電気抵抗の同時測 定中に微小振動を重畳し微分動的弾性率も同時に測定した 結果からも，体積抵抗率の上昇が示すフィラー網目の崩壊 に合せ, 微分貯蔵弾性率の低下, 微分損失弾性率, 微分損 失正接の上昇が確認され，未加硫ゴムにおいてもフィラー 網目の評価に適用可能である事が確認されている ${ }^{13)}$ 。この フィラー網目の崩壊にともなう, 微分貯蔵弾性率の低下, 微分損失弾性率, 微分損失正接の上昇は, フィラーとして シリカを充填した未加硫ゴムにおいても観測され，シリカ 充填未加硫ゴムにおけるフィラー網目評価にも適用可能で ある。
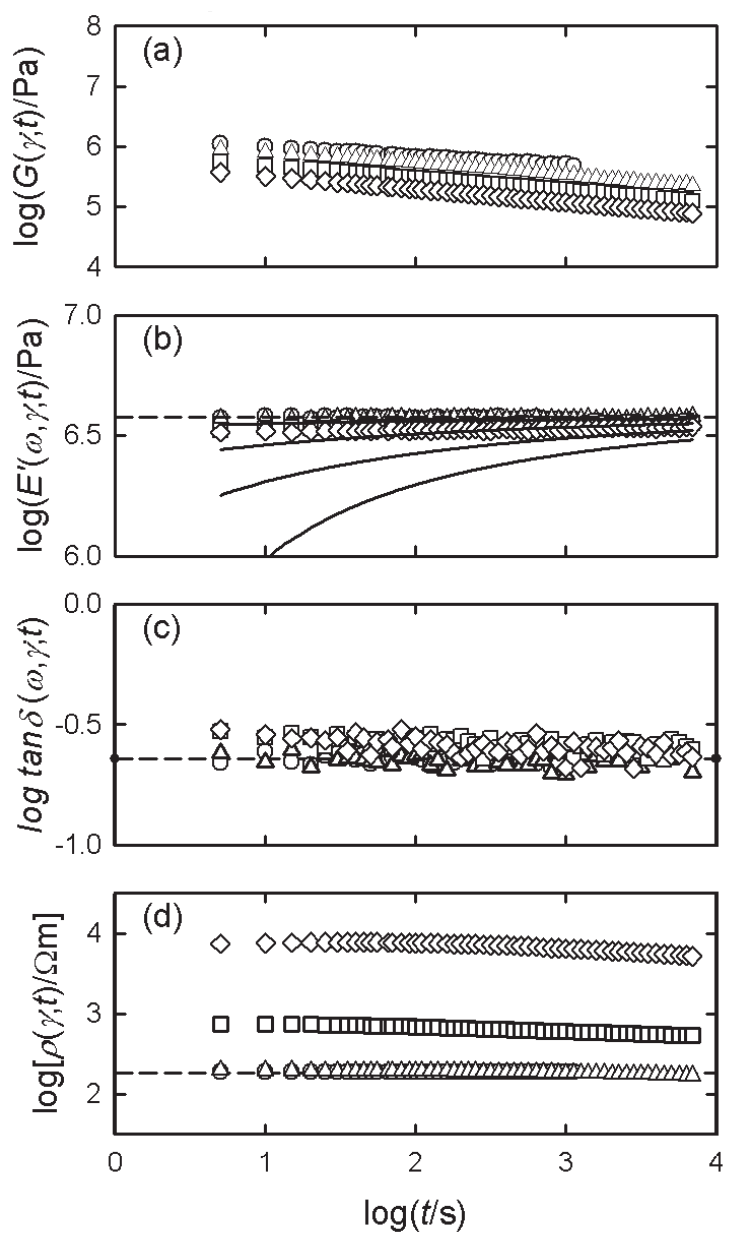

図8 $\mathrm{CB}$ 充填量 $50 \mathrm{phr}$ の試料における緩和弾性率 (a), 微分動的弾 性率 $(b, c)$ ，体積抵抗率 (d) 同時測定結果

\section{3 加工中のゴム内部構造変化}

ここでは, 体積抵抗率と微分動的弾性率により行った変 形過程におけるフィラー網目評価より, 加工中のゴム内部 構造変化に関する考察について紹介する。変形中のゴムの 応力は, 分子鎖の絡み合い構造, $\mathrm{CFN}, \mathrm{BFN}$ の 3 つ因 子により発生していると考えられる。それぞれの寄与を $\sigma_{\mathrm{CeN}}, \sigma_{\mathrm{BFN}}, \sigma_{\mathrm{CFN}}$ と置けば, 全体の応力 $\sigma$ はそれらの和と して書くことが出来る.

$$
\sigma=\sigma_{\mathrm{CeN}}+\sigma_{\mathrm{BFN}}+\sigma_{\mathrm{CFN}}
$$

$\sigma_{\mathrm{CeN}}$ の項はゴムの単位体積当りの分子鎖の絡み合い数 に, $\sigma_{\mathrm{BFN}}$ は単位体積当りの分子鎖の拘束数に依存している と考えられる. したがって, 体積分率 $\phi$ のーボンブラッ クを充填した試料のひずみ $\gamma$, 時刻 $t$ における緩和弾性率 は以下の様に記述できる。

$$
\begin{aligned}
G(\gamma ; t ; \phi) & =(1-\phi) G_{\mathrm{CeN}}(\gamma ; t ; \phi=0)+\phi G_{\mathrm{BFN}}(\gamma ; t ; \phi=1) \\
& +G_{\mathrm{CFN}}(\gamma ; t ; \phi)
\end{aligned}
$$

ゴムの非線形粘弾性は, 緩和弾性率の高さにより議論可 能であり，図7（a）の曲線を議論の対象とすることが可 能である. フィラー未充填試料の曲線は式（2）の第 1 項 のみに依存している. CB 充填 $20 \mathrm{phr}$ の試料の曲線は第 1 項及び第 2 項に, そして CB充填量 $35 \mathrm{phr}$ 以上の試料の曲 線は全ての項に依存している。したがって, CB充填試料 における個々の因子の寄与を図 9 に示すように分離するこ とが出来, 以下の事が確認できる.

○20 phr充填では, $\mathrm{CFN}$ 項の寄与はなく, CeN, BFN, 2つの項が同程度に寄与している.

○3 phr充填試料では, CFNが十分に構築されていな いためにBFN項がCFN，CeN項よりも大きな寄与を 持っている.

$\bigcirc \mathrm{CB}$ 充填量が50 phr 以上の十分にパーコレートしてい る試料では，弾性率はCFN項に支配される。

$\bigcirc \mathrm{CB}$ 充填量の増加にともない, $\mathrm{CFN}$ の寄与はより大き くなる.

OBFN 項は高充填域であっても検出されるが, その寄 与は比較的小さい.

$\bigcirc \mathrm{CeN}$ 項の寄与は消滅することはないが, 高充继域で は無視できるほど小さくなる.

以上の結果より, カーボンブラックの充填量が低い領域 ではBFNが, 高充塡領域ではCFNが重要な役割を果たす と考えられる。また， CFNは， BFNに比べ弱いと考えら れる。したがって，CFNの支配により粘弾性がひずみに 対し敏感になることは当然の結果であると考えられる.

図 9 において, 歪振幅の増加にともないCFNの崩壊に 起因すると考えられる $G(\gamma ; t)$ の大きな低下が観測される. この時, 応力緩和の進行とともに $\mathrm{CFN}$ の回復が起こると 

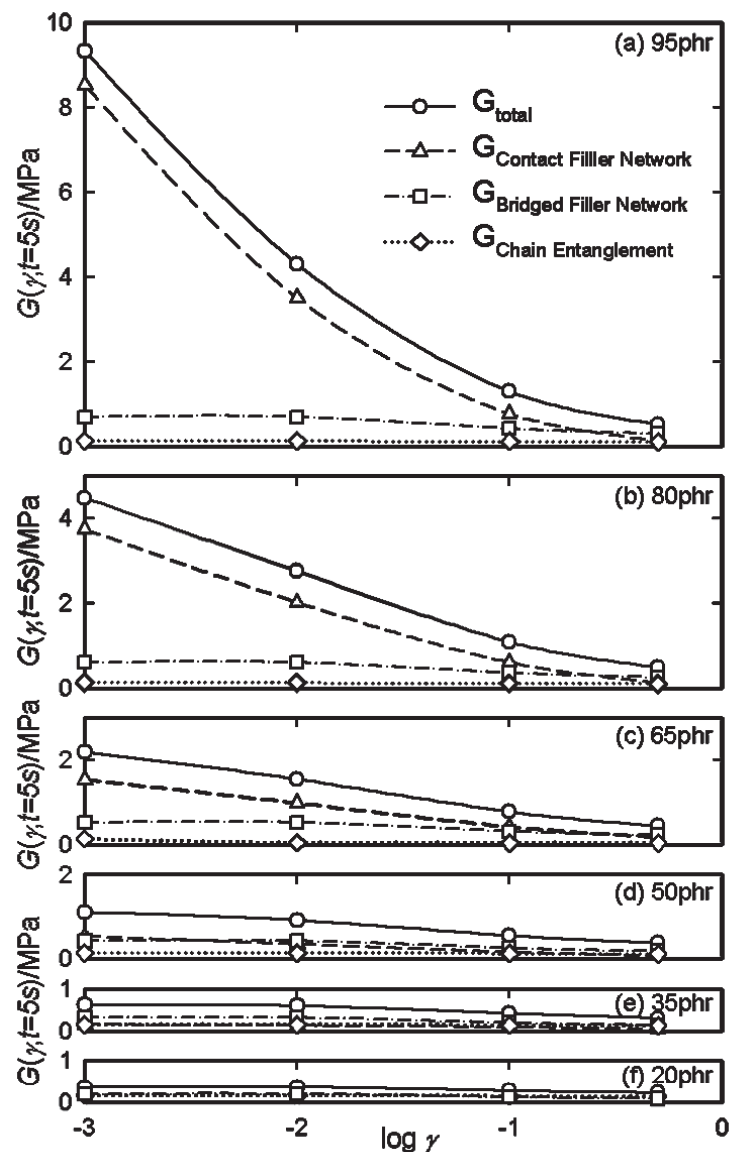

図 9 時刻 $\mathrm{t}=0.1$ 秒での緩和弾性率の歪振幅依存性における $\mathrm{CFN}$, $\mathrm{BFN}, \mathrm{CeN}$ 各項の寄与

しても，新たな構造は応力に寄与しないため $G(\gamma ; t)$ に構 造再形成による変化は現れない。しかし，微分貯蔵弾性率 $E^{\prime}(\omega, \gamma ; t)$ によりその変化が検知可能である. 五十野らは, BKZ 構成方程式を用いて微分貯蔵弾性率を緩和弾性率と 貯蔵弾性率により記述できることを確認した ${ }^{5)}$. BKZ構成 方程式を用いて予測した微分貯蔵弾性率 $E_{\text {av. BKZ }}^{\prime}(\omega, \gamma ; t)$ は 式（3）で見積もられる.

$$
E_{\text {av.BKZ }}^{\prime \prime}(\omega, \gamma ; t)=G(0 ; t) \frac{6}{R^{2}} \int_{0}^{\mathrm{R}}[h(\gamma)-1] r d r+E^{\prime}(\omega, 0)(3)
$$

図10にCB充填量の異なる試料におけるせん断ひずみ $(\gamma=0.001,0.01,0.1,0.5)$ による微分貯蔵弾性率の測定結果と それを用いて計算した $E^{\prime}(\omega, \gamma ; t)$ BKZの予測値を示す。図 10（a）に示す未充填試料において計算值と観測值はおお よそ一致する。しかし， $\mathrm{CB}$ 充填量の増加にともない，特 に高せん断ひずみ域で両者は一致しなくなる，理論より予 測したEav.BKZ $(\omega, \gamma ; t)$ の低下が大きすぎる。観測された $E^{\prime}(\omega, 0)$ の值より予測した $E^{\prime}$ の初期低下が低くなること は, CFNの崩壊に続いて起こる回復過程に起因すると解 釈できる.

ひずみ $\gamma=0.5$, 時刻 $t=5 \mathrm{~s}$ における $\rho(\gamma ; t) / \rho(0)$ と $E^{*}(\omega$, $\gamma ; t) / E^{\prime}(\omega, 0)$ のCB充填量依存曲線を図 11 に示す. BKZ理 論により緩和弾性率から予測した $E(\omega, \gamma ; t)$ の值は, $\mathrm{CB}$ 充 填量の増加とともに徐々に減少する。崩壊したCFNが回
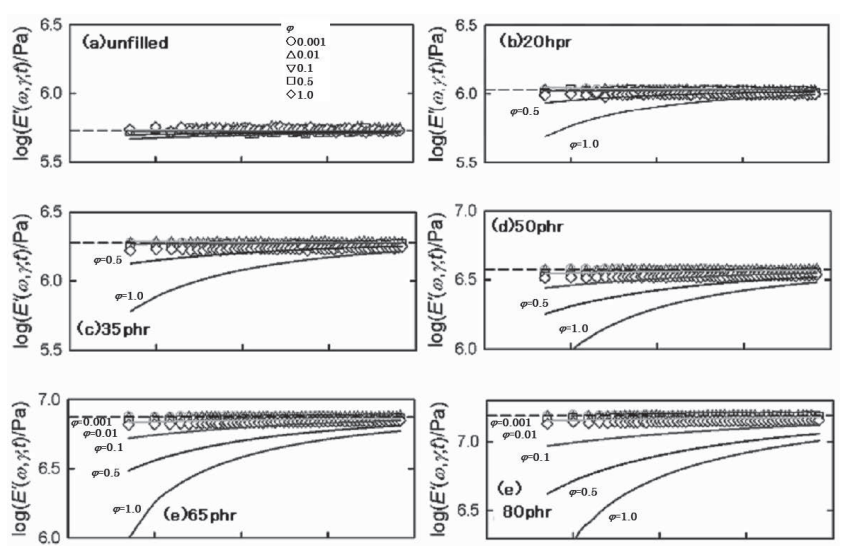

図10 CB 充填量の異なる試料に打けるせん断ひずみ $(\gamma=$ 0.001,0.01,0.1,0.5) による微分䝪蔵弾性率の測定結果とBKZの 予測值（実線）

復しないのならば, $E(\omega, \gamma ; t)$ は図11（b）が示すように, $\mathrm{CB}$ 充填量の増加とともに徐々に減少するはずである。し かし, 観測された緩和応力から求めた $E^{\prime}(\omega, \gamma ; t) / E^{\prime}(\omega, 0)$ ははるかに大きく, 実際には応力緩和中に $\mathrm{CFN}$ の速い回 復過程が存在すると考えられる。この速い回復過程は主に CFNが密に存在しているために生じると考えられる. 例 えば, 二つの隣り合ったずり面に打ける二つの接触した CB凝集体を仮定すると，せん断変形が与えられたとき， 一つの凝集体はもう一方から離れていく，しかし，CBが 高充填された系中では，その凝集体は高い確率で新たな凝 集体に衝突すると考えられる。 そして，その確率は $\mathrm{CB} の$

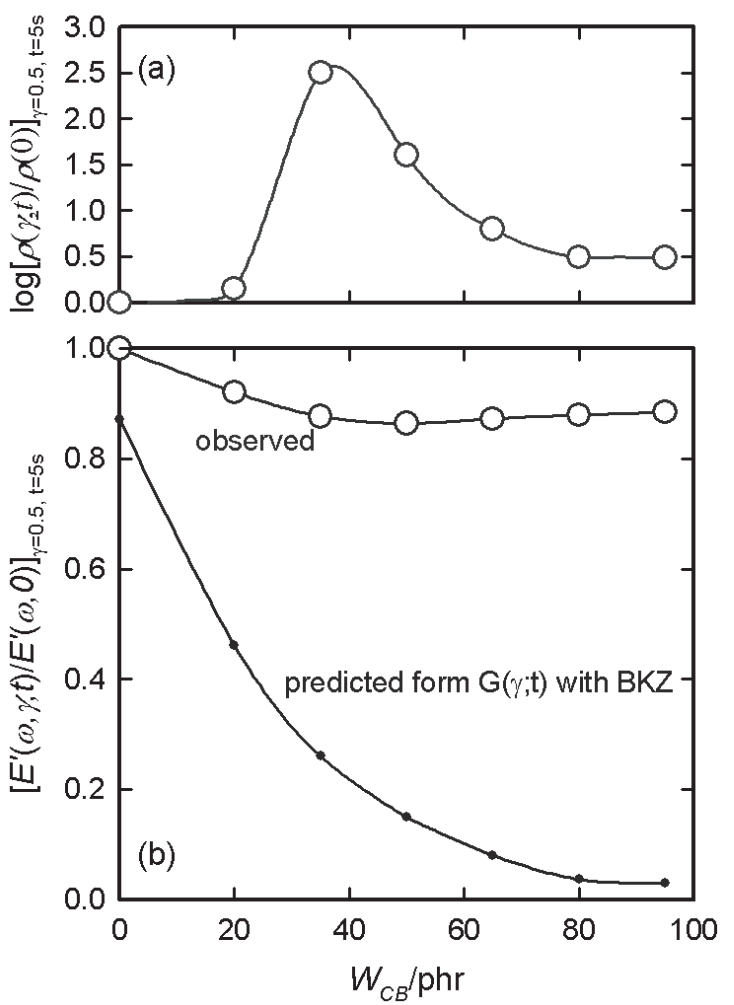

図 11 体積抵抗率変化と微分貯蔵弾性率変化 $\mathrm{CB}$ 充填量依存曲線 $(\gamma=0.5, \quad t=5 \mathrm{~s})$ 
充填量が増えるにつれ増加する。その上， BFNとしてフ イラー粒子間に拘束されたポリマー分子鎖が伸ばされたこ とにより生じた収縮力もまたCFNの再構築に寄与すると 考えられる。 この推測は, 図 9 に示したようにBFNが大 変形下でも存在し続け, 応力への寄与が弱いひずみ依存性 を示すことからも支持される，つまり，加工中にゴムの内 部では, $\mathrm{CFN}$ の崩壊と回復 (再構築) が生じており, そ の回復には, BFNとして拘束された高分子鎖が強く関与 していると考えられ，加工工程において BFNの挙動を制 御することが重要な課題となる.

\section{4. お わりに}

ゴム加工工程では，ゴムは未加硫の状態で大変形を受け 加工される．また，そのような大変形条件下ではフィラー 充填ゴムは顕著な非線形性を示す．この未加硫ゴム（他補 強層との複合材として取り扱う場合も含め）の大変形挙動 は，有限要素法などのシミュレーションを適用する事が可 能である. 比較的小さな変形域での挙動に対しては, 未加 硫ゴムを構造体として取り扱うことが可能である。また, 流動を伴うような大変形領域での挙動については, リメッ シュ法や，フリーメッシュ法などを適用すること，あるい はゴムそのものを流体として定義して成形流動シミュレー ションや流体解析を適用する事で, その挙動を見積もる事 が可能である，一方，フィラー充填ゴムが示す顕著な非線 形性に関しては，フィラー網目評価技術によりゴムの内部 構造変化を検知し解釈する事が可能である。 フィラー網目 評価には, 電気抵抗や微分動的弾性率の測定が有効であ
り, 加工中にゴムの内部では, CFNの崩壊と回復（再構 築）が生じており，その回復には，BFNとして拘束され た高分子鎖が強く関与していると考えられる. 以上より, ゴムの非線形挙動の源である内部構造変化, 特にBFNの 存在を加味した材料特性を組み込んだ材料モデルによるシ ミュレーションを実施することが, ゴムの加工性を含んだ 大変形・流動挙動を再現するシミュレーション技術の進化 につながるものと考える.

\section{References}

1 ) Erami, T.: 195th Gomu Gijutsu Symposium, 30 (2013)

2 ) Isono, Y.; Ohashi, N.; Kase, T.: Macromolecules, 28, 5154 (1995)

3 ) Isono, Y.; Nishitake, T.: Polymer, 36, 1635 (1995)

4 ) Isono, Y.; Kamohara, T.; Takano, A.; Kase, T.: Rheol. Acta, 36, 245 (1997)

5 ) Isono, Y.; Ferry, J. D.: Rubber Chem. Technol., 57, 925 (1984)

6 ) Isono, Y.; Ferry, J. D.: J. Rheol., 29, 273 (1985)

7 ) Klueppel, M.: Adv. Polym. Sci., 164, 1 (2003)

8 ) Medalia, A.: Rubber Chem. Technol., 51, 437 (1978)

9 ) Barrès, C.; Mongruel, A.; Cartault, M.; Leblanc, J. L.: J. Appl. Polym. Sci., 87, 31 (2003)

10) Karasek, L.; Meissner, B.; Asai, S.; Sumita, M.: Polym. J., 28, 121 (1996)

11) Kohjiya, S.; Katoh, A.; Suda, T.; Shimanuki, J.; Ikeda, Y.: Polymer, 47, 3298 (2006)

12) Isono,Y.: Nippon Gomu Kyokaishi, 86, 106 (2013)

13) Satoh, Y.; Fujii, S.; Kawahara, S.; Isono, Y.; Kagami, S.: e-J. Soft Mater., 3, 29 (2007)

\section{日本語表記参考文献}

1 ）撰隆文：第195回ゴム技術シンポジウム，30（2013） 